\title{
Dynamics of Fodder Resources of the Most Important Fodder Plants of the Winter Pastures of North-Western Part of Azerbaijan
}

\author{
K. K. Asadova ${ }^{1}$ \\ ${ }^{1}$ Geobotany Department of the Botany Institute of the ANAS, Azerbaijan \\ Correspondence: K. K. Asadova, Geobotany Department of the Botany Institute of the ANAS, Azerbaijan. \\ E-mail: sayyarajamshid@yahoo.com
}

Received: September 26, 2012 Accepted: October 28, 2012 Online Published: December 10, 2012

doi:10.5539/sar.v2n2p29 URL: http://dx.doi.org/10.5539/sar.v2n2p29

\begin{abstract}
Feeding value of desert, semi-desert and arid plain winter pastures of the North-Western part of Azerbaijan is considered in the article. Data on dynamics of fodder resources and features of the major plants of the winter pastures of the region are given. A chart-scheme of main types of vegetation of winter pastures is cited. A brief evaluation of present-day condition of pastures and recommendations in the further exploitation are given.
\end{abstract}

Keywords: fodder plants, winter pastures, desert vegetation, ephemerae

\section{Introduction}

Natural vegetation of arid steppes, deserts and semi-deserts of Azerbaijan serves as satisfactory forage during the winter, spring and autumn and it is considered as winter pasture. These fodder pastures have enormous significance for rural economy of the republic as a cheap forage base to develop and strengthen efficiency of cattle-breeding. They provide cattle-breeding industries with forage within 6-8 months in a year (October to May). Dynamics of fodder resources and properties of dominating plants of winter pastures of the region is considered in detail in the article. Particularly geobotanical classification of the deserted, semi-deserted and arid steppe pastures of north-western part of Azerbaijan is provided. A card-scheme of the basic types of vegetation of winter pastures is adduced. Brief evaluation of the state of pastures and recommendations in the further exploitation are given.

\section{Materials and Methods}

The research was carried out by the standard methods of geobotany (Prilipco, 1954) and had a detailed-routing and semi-stationer character. Taking into account that geobotanical researches are periodically carried out every 5 years average data have been given in the article recently. Desert, semidesert and arid plain cenoses of the North-Western part of Azerbaijan served as objects. The investigation was carried out in the period of active vegetation and fructification of vegetation, i.e. in spring (April to May) and in autumn (October to November). In the abovementioned cenoses that served as pasture plots were put in accordance with the methodological recommendations. The description on the plots was carried out by compiling of a plant list by abundance indication of each species, phenophase, pasturing and other geobotanical indices (height, vitality, project covers and phonological observations.)

The harvest was defined twice in spring (April to May) and in autumn (October to November) to ascertain dynamics of gross feedstock during a year. Productivity of grassy vegetation was taken into account by the method of cut from the plot with dimension of $140 \times 40 \mathrm{~cm}\left(0,4 \mathrm{~m}^{2}\right) /$ ha .

\section{Results and Discussion}

Study of the vegetation of a North-Western part of Azerbaijan has got long-period history. The Most detailed researches were carried out since the second half of the XIX Century and since the beginning of the XX Century here (Asadova, 2006; Ahmadova, 2004; Hajiev, 1979; Grossgeym, 1929).

North-Western part of the republic according to botanical-geographical division concerns to northern part of Small Caucasus of Azerbaijan. Vegetation does not develop on young geological rocks on the areas with these soils. The region is characterized by a mild, warm, half-dry, continental climate.

Average temperature of the warmest month is $22-24^{\circ}$, the coldest temperature is $-20^{\circ}$ and mid-annual temperature 
is $+6,1+13,2^{\circ} \mathrm{C}$. In summer period keen temperature drops abrupt junctions of air are observed (Museibov, 2001). A very hot day $\left(+38^{\circ} \mathrm{C}+40^{\circ} \mathrm{C}\right)$ is replaced with a cool night. Distribution of precipitation unequal greatest quantity of moisture is on the first half of spring and autumn, i.e. for the beginning vegetations (spring) and renewal (autumn) of ephemeras synusia and ephemeroids.

Winter pasture territories of the region according to the division offered by L.I.Prilipco concern to a zone of steppe plateau. Average height of the territory is $400-600 \mathrm{~m}$ above the world sea-level; the lowest height of the territory is $250 \mathrm{~m}$ and the highest one is $800-900 \mathrm{~m}$. Concerning to the landscapes in the territory lowlands and hilly foothills differ from each-other. One can observe interesting combinations and alternations of flat sites with increase of various sizes and heights.

Lower mountainous areas are formed by arid-denudation forms of a relief and include arid valleys, ravines, bed lands et al. Arid zones of the region represent adjournment of the ancient 3-rd Period (Tertiary) and current depositions in the geological plan. Brown and grey-brown deserted soils with saline fragments [M.A.Bayramov, 2002] were well expressed in winter pasture territories of the region. In foothill zones they cover transitive position between chestnut soils and grey soils. In comparison with chestnut soils capacity of horizon of the last ones is insignificant: 6 to $16-17 \mathrm{~cm}$. The general capacity of the humus horizon does not exceed $50-55 \mathrm{~cm}$.

Content of humus in the upper horizon is 1, 5-3,0\%. There are rocky soils not considerably spread and sometimes met on slopes of the ridges. General sparseness of the vegetation cover is characteristic for desert and semi-desert parts of the region. Arid-steppe phytocenoses are differed with their big projective cover. As a part of the vegetation cover two main ecotypes of plants dominate; they are: xerophytes, half-bushy and a special group of xeromesophyte ephemerae and ephemeroids. Expressed complexity of the vegetation cover that is expressed in changes of various formations, associations and groupings (a map-scheme 1) is characteristic.

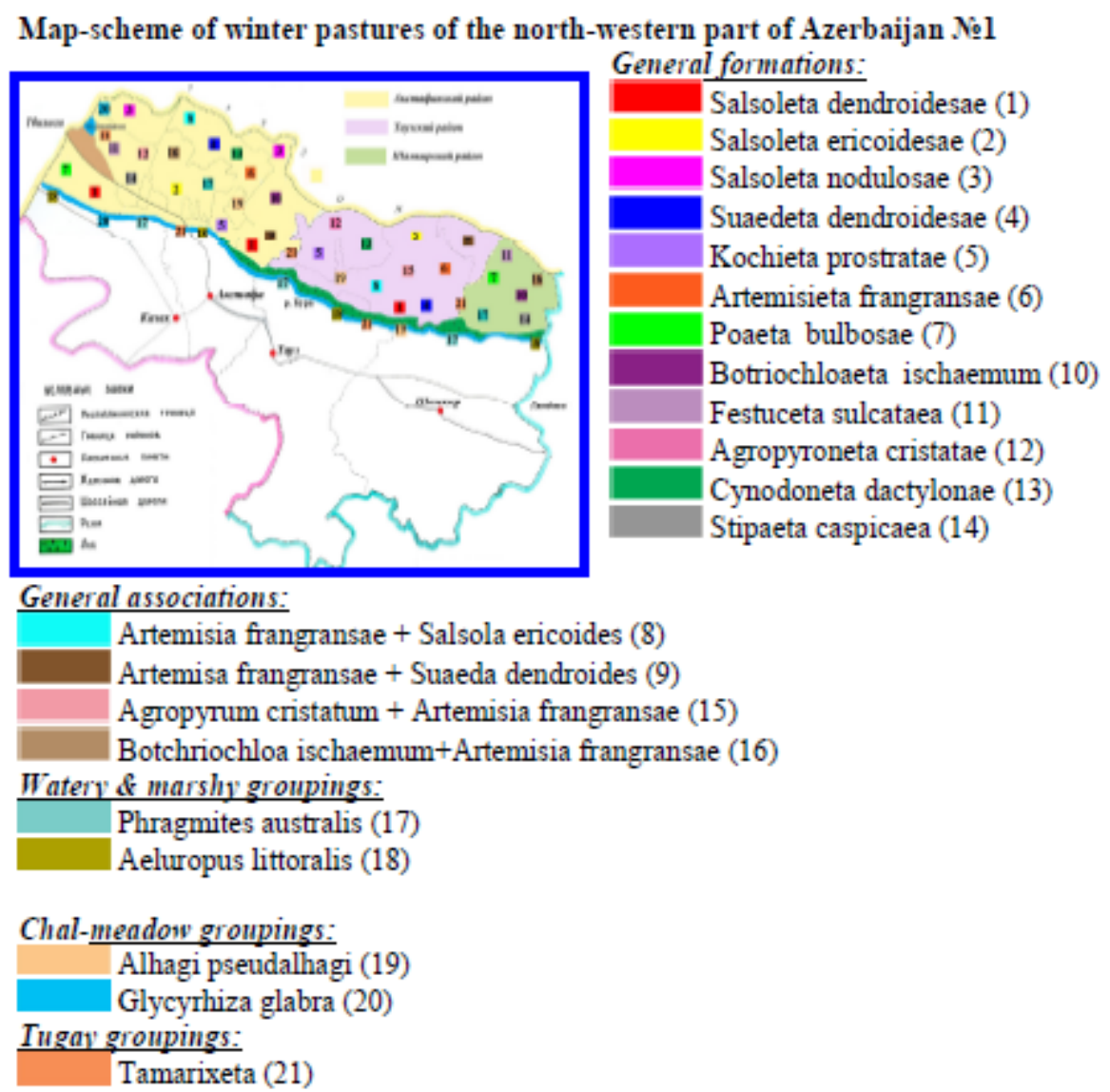

Among the main ecological factors effecting onto character of vegetation - a water mode is on the first place. A bit alteration of humidity supply affects on vegetation at once, causing a change in the structural content of 
communities. Anthropogenic factor is not less influential. First of all irrigation of a vegetative cover effects onto irrigation changing a course of physical and chemical soil processes that involves on adjacent places in areas of catastrophic change of natural xerophylic vegetation into weedy hydromesophyte one (marsh, marsh and meadow, meadow). Dry (not irrigated) agriculture and pasture also destroy vegetation cover, changing character of upper soil horizons, thereby causing erosion of soils.

The most widespread types of vegetation of winter pastures are deserted, semideserted and arid-steppe. partly depending on a relief and etc. soils in marsh and meadow, again-weedy (adventive) types are locally met. Except the types listed above in areas of the left bank of Iora and Kür (Kura - Russian version) rivers forest and bush of Tugay thickets type of the Tamarix L., Salix L. genera and also chal-meadow vegetation were extended. Content of the last one depends on salinity degree in many respects. In the case of strong salinity meadow-halophyte groupings with participation of Salsola dendroides Pall. Dominate here; in the case of weak salinity the groupings with participation of Glycyrrhiza glabra L. and cereals.

According to species number the group of half-bushy and bushy fodder plants takes an insignificant place (about 30species). However a number of their representatives as: Artemisia fragrans Web, Salsola nodulosa (Moq.) Iljin, S. dendroides, S. ericoides Bieb. et al. like an additional and insurance fund for the cattle maintenance on pastures and also have got exclusively great significance. All of them are characterized by the long vegetation period beginning in March-April and coming to an end in November-December. Bushes, semibushes and small bushes as forage for cattle are generally used during the autumn-winter period of pastures. Common property of these plants is their bad pasturing in vegetation period and satisfactory pasturing upon the end of vegetation. The greatest fodder significance among this group has got wormwood, S. dendroides and S. nadulosa.

Fodder resources of separate glassworts Salsola, vary not only depending on a habitat, but also on meteorological conditions. In fructification period they are considered as good fodder plants especially after frosts. Intensive pasturing of annual fodder glassworts Salsola is observed during the autumn period and in the first half of winter. Significance of bushes and semibushes especially increases during a snowfall when all grassy vegetation is covered by snow. In this period bushes and semibushes are the insurance plants providing cattle by forage. Having adapted to arid climatic conditions of deserts and semi-deserts and developed owing to the corresponding vital rhythm, many ephemeras became the basic accompanying components of fodder grounds of pastures. Due to a superficial arrangement of root systems of ephemeras in soil, they are adapted for fast humidifying by insignificant quantity of the precipitation that are dropping out during autumn and spring. It completely provides them with necessary moisture for fast re-growth.

Start of vegetation of the group of plants is observed after the first autumn rains (in September and October). Meanwhile grow of not only representatives of ephemeras appears in the pastures, but also long-term fodder plants. Especially dense green shoots are provided by Poa, different species of Aegilops, Bromus, Lolium, Agropyron and others. The carried out analysis of pasturing dynamics of cereal fodder plants according to seasons of a year to large and small horned cattle (Figures 1-10) showed interrelation of a temperature mode with rates of vegetation and a gain of plants with pasturing character. Apparently from the figures, majority of them is well eaten by small horned cattle during the spring period when the top of cereals has not coarsened yet.

The majority of steppe plants have got important fodder significance. Cereals also are on the basic place among these pasture grasses. They are well eaten by cattle and are of the most considerable part of pasture forage. Not less valuable components of pastures are leguminous, differing with its high content of protein. Only separate species according to their fodder value don't concede to cereals and leguminous. They are in most cases badly eaten or not eaten by cattle at all.

The factor defining optimum development of cereals during the period from the middle of March to the middle of April is the thermal mode. From the middle of April to May it is a thermal mode and there is moisture stock in soil. In summer soil moisture regulated in air temperature has reserved; from the middle of September till October there is soil moisture; in October-November there is a thermal mode connected with a cold snap and in winter-a snow cover. Gain value and consequently productivity from spring, autumn and till the winter are varied from $60 \%$ (spring) to $20 \%$ (beginning of summer) and $10 \%$ (winter). In herbages mainly annual cereals basically ephemerae play a big role. A group of ephemeroids that is almost similar with the annuals according to its biology among long-term cereals is allocated. Prominent feature of long-term cereals is that after semination their surface bodies die off only and their restoration occurs every year after autumn rains. Vegetative restoration is the basic way of restoration of a herbage on pastures and has exclusively great value in perennial cereals life. 


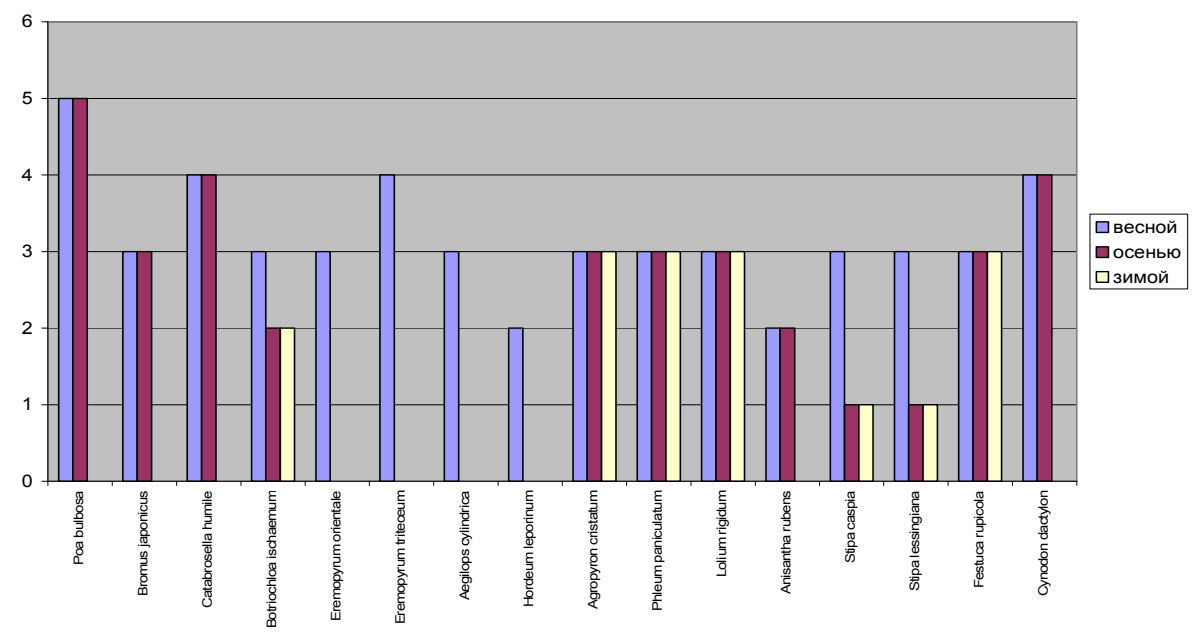

Figure 1. Pasturing dynamics of the basic cereal fodder plants according to seasons of a year by small horned cattle (sheep and goats)

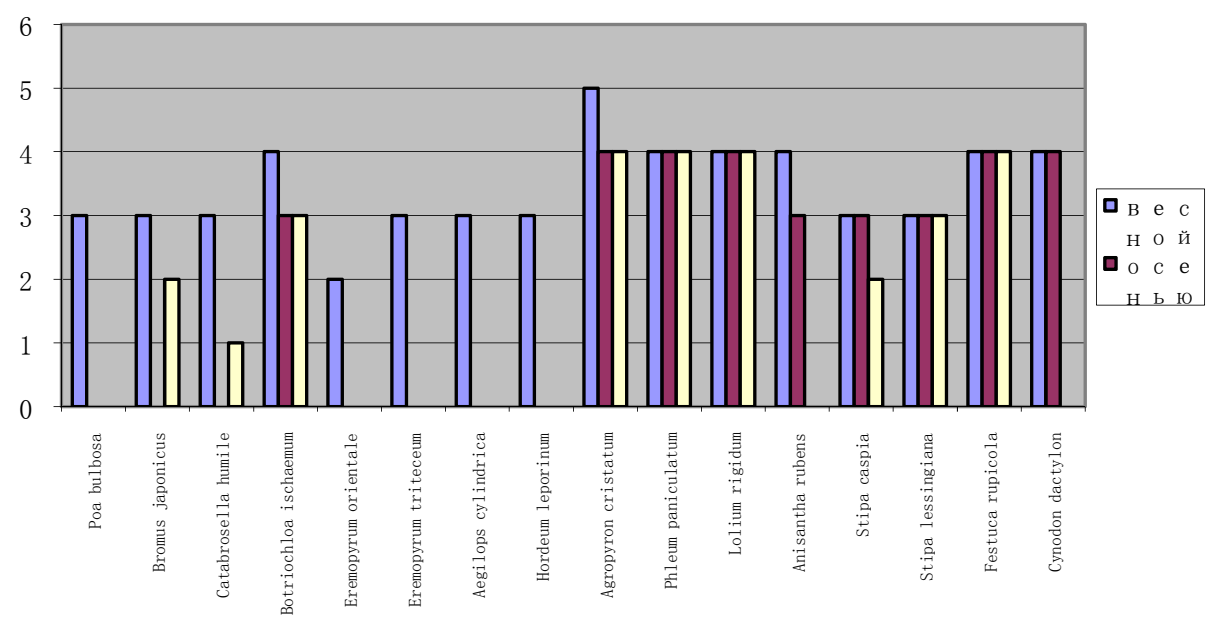

Figure 2. Pasturing dynamics of the basic cereal fodder plants according to seasons of a year by large horned cattle (cows, buffaloes)

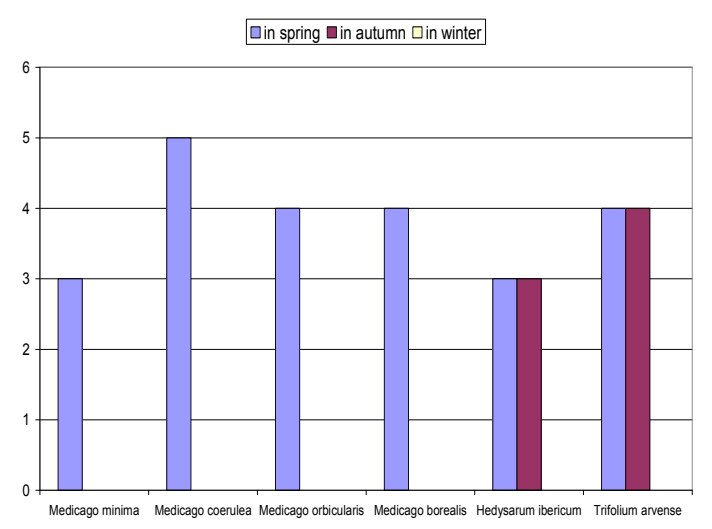

Figure 3. Pasturing dynamics of the basic leguminous, fodder plants according to seasons of a year by small horned cattle (sheep and goats)

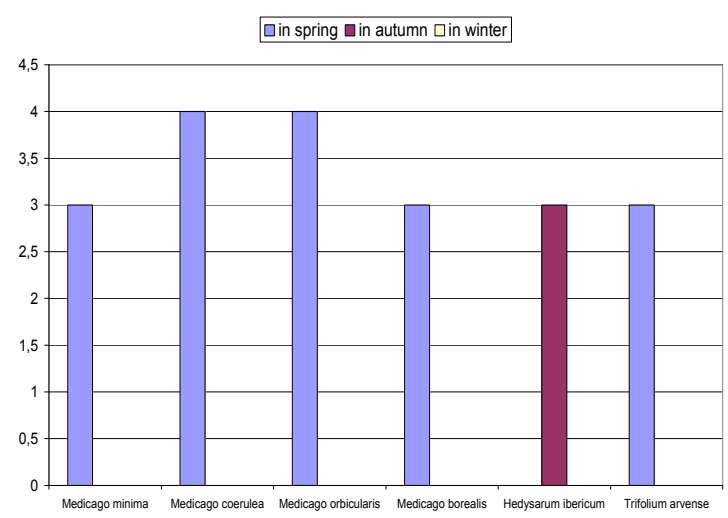

Figure 4. Pasturing dynamics of the basic leguminous fodder plants according to seasons of a year by large horned cattle (cows, buffaloes) 


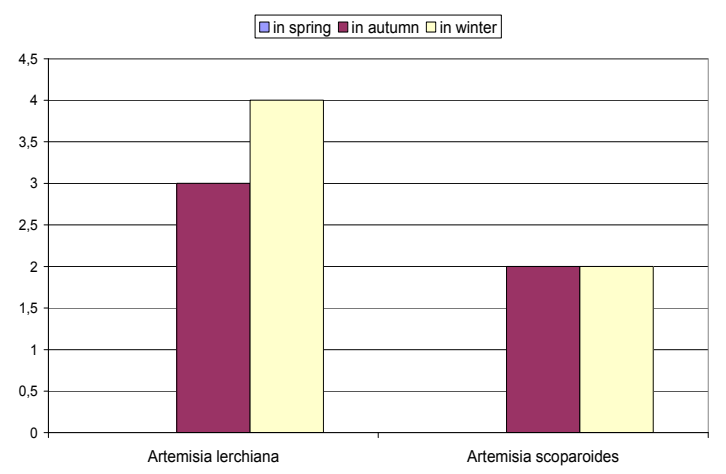

Figure 5. Pasturing dynamics of wormwood fodder plants according to seasons of a year by small horned cattle (sheep and goats)

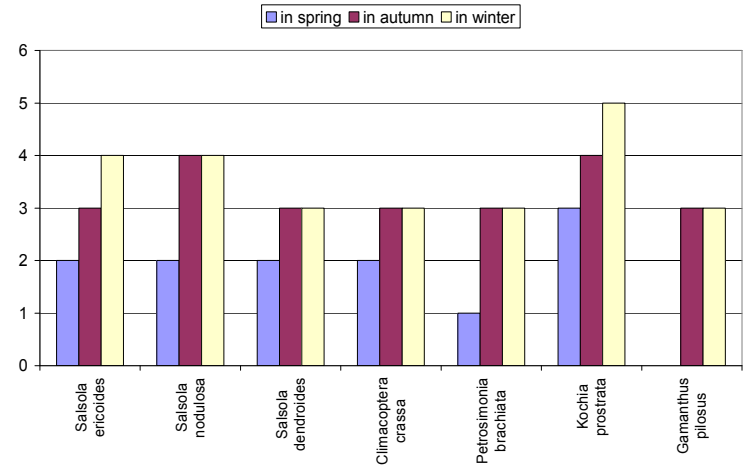

Figure 7. Pasturing dynamics of basic glasswort Salsola fodder plants according to seasons of a year by small horned cattle (sheep and goats)

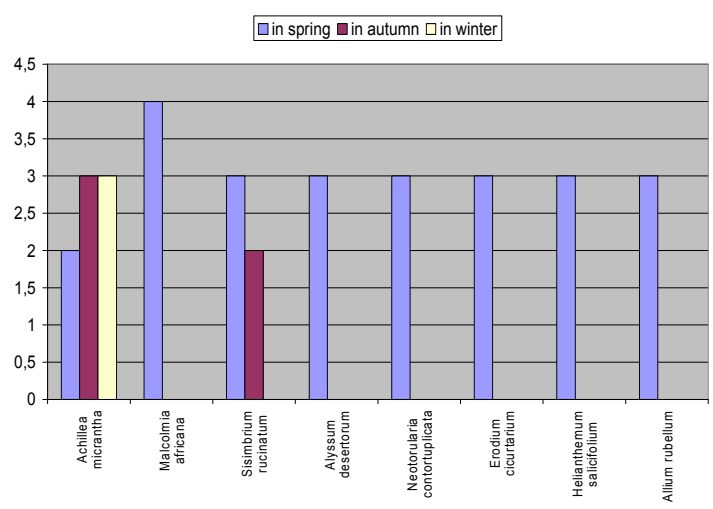

Figure 9. Pasturing dynamics of the basic ephemera-herbs fodder plants according to seasons of a year by small horned cattle (sheep and goats)

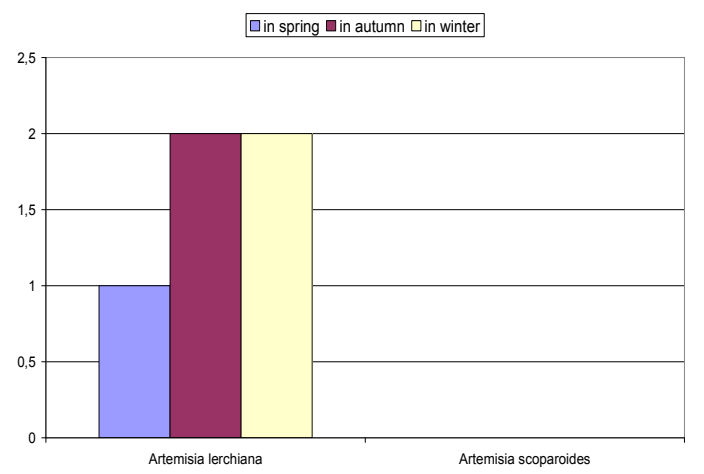

Figure 6. Pasturing dynamics of wormwood fodder plants according to seasons of a year by large horned cattle (cows, buffaloes)

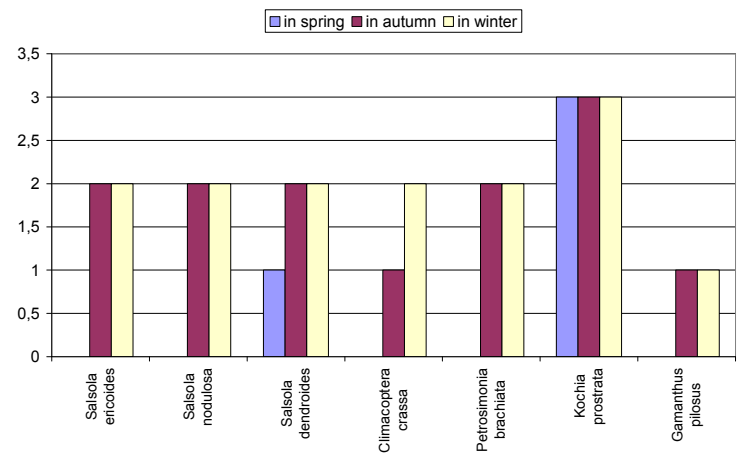

Figure 8. Pasturing dynamics of basic glasswort Salsola fodder plants according to seasons of a year by large horned cattle (cows, buffaloes)

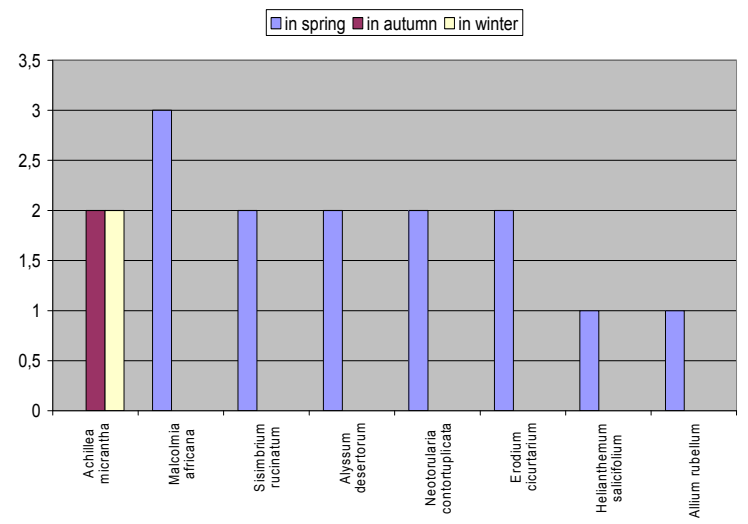

Figure 10. Pasturing dynamics of the basic ephemera-herbs fodder plants according to seasons of a year by large horned cattle (cows, buffaloes)

In the majority cereals are presented by xerophyilic and mesoxerophyilic ecoforms. Their content includes such species as: Agropyron cristatum (L.) Beauv, aegilops cylindrical (Aegilops cylindrica Host.), ryegrass rigid (Lolium rigidum Gaudin), Bromus japonicus Thanb., Stipa lessingiana Trin.ex Rupr., bluegrass styptic Andropogon/Botriochloa ischaemum (L.) Keng et al. These representatives vegetate during autumn-spring period and in the first half of summer. Their flowering and fructification usually occurs in the beginning or in the middle of June; grow begins in the autumn after the first autumn rains (IX-X). Beginning of vegetation at beard grass Andropogon/Botriochloa ischaemum (L.) Keng is adapted for the summer pasture period. In the stage of 
cutting and ear formation xerophylic cereals contain significant amount of nutrients. At the same time they are perfectly eaten by cattle. Among the mentioned perennial xerophylic cereals mainly feather grass species are badly eaten. Xeromesophylic cereals are met not so much in the field of deserts. The typical of them: aegilops, awnchaffs, darnel rigid et al. give their shoots in autumn, after first rains and in spring. In relation to salinity of substrata among cereals the group of halophylic cereals is allocated. They are divided into annual and perennial halophylic cereals. The first ones (annuals) almost don't differ from usual ephemeral cereals according to their fodder and biological properties and have got exclusively positive significance for pasturing in saline pastures during autumn-spring period. The majority of representatives of this group are willingly pasturing to ear formation. During the early-autumn period when other fodder grasses are absent dry rests on roots of these plants are carefully taken up and very much willingly eaten by small cattle (especially sheep and goats). Nutritiousness of such halophylic cereals is very high. Content of perennial halophylic cereals is rather insignificant.

Leguminous grasses differ with their high content of fodder protein. Due to its chemical content the plants of this family are the most valuable component of pasture forage. As a part of steppe herbages in different variants Lucerne/Medicago minima (L.) Bartalini, sickle alfalfa (Medicago falcata), Lucerne crescent/M. rigidula (L.) All., Lucerne blue/M. coerulea Less. et Ledeb., et al. can be widely presented. Good fodder plants of this fodder group are also Trifolium arvense L., Trigonella orthoceras Kar. et Kit., Melilotus albus et al.

The group miscellaneous herbs include mainly representatives of families (Chenopodiaceae Vent.) Asteraceae Dumort., Caryophyllaceae Juss.. Representatives of Salsola/Chenopodiaceae, were extended in deserts and are inhabitants of the saline territories, accept considerable participation in formation of hollophile vegetation.

Many species of this family serve as fattened plants for sheep, camels and other breeds of cattle in the autumn-winter periods. They are: Salsola nodulosa (Moq.) Iljin.), Salsola treelike/Salsola dendroides Pall., Kochia prostrata L., Salsola dense-flowered/Salsola ericoides Bieb., (Kochia prostrata L.), et al. Representative of the Asteraceae family, wormwood/Artemisia fragrant Web. xerophylic semibush, landscape plant of the East Transcaucasian lowland covers the huge areas of winter pastures. Atmospheric precipitation is of a great importance for satisfied seasonal development of wormwood. In spring they define growth, seed germination and development of plant shoots. In summer they prolong the vegetative period of wormwood, increase its growth. They provide generation in autumn. And in winter dropping out snow promotes increase of moisture resource, providing with wormwood crop.

Eaten parts at wormwood are mainly live branches of the current year, leaves and partially branches of last year; the last ones are eaten mainly in early spring together with grown young sprouts. Not fructifying sprouts remained a bit woodened till winter especially are willingly eaten in autumn and winter. Average crop of wormwood Artemisia in spring can reach approximately 2.5 centner/ha, and in autumn approximately 12-13centner/ha. Representatives of the Shenopodiaceae Family as: Russian thistle, glasswort, saltwort, (Salsola nodulosa)-haloxerophyte small sub shrub, 10 to $40 \mathrm{~cm}$ of height, with awl-shaped trihedral, early falling down small leaves. Stalks in the bottom part are stiffened and covered with a light grey bark.

Vegetation beginning (Salsola nodulosa) saltwort occurs in spring in the middle or end of March. During summer period, owing to air rise in temperature, shoots it growth are slowed down. Flowering of Salsola nodulosa usually begins in August, and fructification in September-October, the maximum formation of green mass at the end of autumn. It is a fattener plant and it is well eaten almost by all kinds of cattle on pastures.

Eaten parts of (Salsola nodulosa) are young branches with small reduced by blotched leaves. Salsola nodulosa is the important fodder plant of winter pastures and especially are willingly eaten by sheep. In April-May the fodder weight of Salsola nodulosa is 2,5-3centner/hectares, and the winter period is a parity varies averagely for 13-14centner/hectares. In autumn it has a decorative appearance in fructification, giving to desert yellow-purple-orange aspect; on clay slopes it is a fixer of soils, i.e. and interferes with development of erosive processes.

Saltwort treelike (Salsola dendroides)-pea shrub (Caragana). A semi-bush that height can reach $80-100 \mathrm{~cm}$. Shoots of pea shrub (Caragana) develop all summer long till autumn, forming considerable vegetative ground. To the middle of autumn stalks of pea shrub (Caragana) reach full maturity; its flowering begins with second half of September, fructification occurs in October-November. In December and January all elevated parts of pea shrub (Caragana) dry out and they remain in such state till the spring. Young shoots of pea shrub (Caragana) are eaten by sheep reluctantly in spring, satisfied and well in autumn and in winter especially after frosts and better in moistened state when rough branches are considerably softened after rain (dew). Pea shrub (Caragana) is adapted mainly to an along river strip of the Kür in winter pastures, therefore its role in general fodder balance is rather small. 
Glasswort ericet-shaped-(Salsola ericoides). Small bush of about $1 \mathrm{~m}$ height, blossoming/fruit-bearing May-October. It grows in salted, saline, gray soils, and brown deserted soils. It's well eaten by cattle during winter and autumn. According to data the flora of Azerbaijan serves as a source for handicraft extraction of soda.

In a vegetation phase glasswort ericet-shaped-(Salsola ericoides) contains protein-11,61\%, albumen-8,02\%, fats-1,14\%. According to our survey after frosts and the first snow pasturing of plants raises. By May fodder weight glasswort ericet-shaped (Salsola ericoides) hesitates 1 to 2,5centner/hectares (dry weight). By the end of autumn and in beginning of winter it is averagely 12-14centner/hectares.

Kochia spread (Kochia prostrata), leban (Vitex) semi-bush that mostly grows single. Height of stalks often reaches up to $10-75 \mathrm{~cm}$.

This plant gravitates to dry steppes and semi-deserts in the region. Chemical compound of kochia (Kochia) has a number of the features distinguishing it from the majority of Chenopodiaceae Family, cereals and bean. In comparison with other representatives of Chenopodiaceae Family they contain not enough ashes (according to the average data $10,6-14,0 \%)$, in comparison with bean and cereals there is not enough fat $(1,5-2,5 \%)$; a protein and protein contains big than at cereals (flowering of 13,3 both 10,6\% and fructification of 10,4 and 8,6\%) and less than at bean, but celluloses of kochia (Kochia) contains more (flowering - fructification of 33,1-35,2\%); nitrogen-free extracts are less than the extracts at cereals and bean. According to these data kochia (Kochia) on the general nutritional value is not lower than average cereal and bean hay. According to contain of protein it is closer to bean, than to cereals. Thanked to its content kochia (Kochia) concerns to a group of first grade fodder plants and it is well eaten by cattle.

Species like Tragopogon graminifolius DC. species of the genera Calendula L., Taraxum L., Centaurea L., et al. of the Compositae family were extended. Brassicaceae Burnett.was richly presented in the pastures of the area. The species Strigosella africana (L.) Botsch., Alyssum calycinum L., Neotorularia contortuplicata (Steph.) O.E.Schulz have been presented with a greatest abundance. All of them are ephemerae-wormwood components, wormwood-glasswort (Salsola), glasswort (Salsola) pastures and are well eaten by small horned livestock. In warm and rainy spring these plants increase their abundance from 2-3 points to 3-4. Well eaten by cattle plants are also the followings: Strigosella africana (L.) Botsch. (It is well eaten by cattle, in a vegetation initial stage); Alyssum calycinum L. (Before fructification it is especially well eaten by small horned livestock); Neotorularia contortuplicata (Stepf.) Hedge et J.Leonard (It is eaten well by all breeds of cattle); Erodium cicutarium (L.) L.Her. (It is well eaten by sheep); Heliantemum salicifolium (L.) Mill. (it is well eaten by all kinds of cattle before flowering); Bupleurum rotundefolium L. (it is well eaten by all breeds of cattle before flowering); Ferula caspica Bieb. (it is well eaten by all breeds of cattle before flowering); Allium rubellum Bieb. (It is well eaten by small horned livestock before flowering).

Concerning to fodder according to the region it was ascertained by us: at present $62.3 \%$ of the species were well eaten ones and $16.2 \%$ species badly eaten. The number of perfectly and well eaten plants is rather limited and it makes $16,2 \%$.

\section{Conclusions}

3types were given in the fodder pastures of the region: desert, semi-desert and steppe joining 6 formation classes, 7 formation groups, 16 formations and 26 associations and prevalent zonal one is desert. It was ascertained as a result of long period unmethodical and irregular exploitation of vegetation of the region it has strongly violated. It demands urgent measurements for improvement. Concerning to it we consider use of alternating system of live-stock pasture, execution of works to improve pastures, foundation of long-term pastures by intercropping of local wild and perennial fodder cultivars (cereals, Russian thistles and leguminous). Evaluating the current situation of the natural fodder lands of the research area we note that $90 \%$ of winter pastures of the region were pastures of the first category in its time. However for today as a result of active effect of the anthropogenic factor $70-75 \%$ of this area has passed in the lowest category. The overload of herbage with cattle involves formation of terraces and facilitates soil denudation, and often even to its washout and a pulling down by rains, the progressing phenomenon of erosion. In further use the inconvenient earths should be completely cultivated and transformed into full productive fodder grounds and first of all the salinity soils should be mastered.

\section{Reference}

Asadova, K. K. (2006a). Actions on rational use of winter pastures of Jeyranchel Area. News of the Azerbaijan State University, Baku, pp. 337-339.

Asadova, K. K. (2006b). Current state of natural fodder grounds of the Jeyranchel Area of Azerbaijan//Transactions of Institute of Botany, Baku, pp. 200-203. 
Ahmadova, S. Z. (2004). Biodiversity of the plant cover ecosystem of Jeyranchel Area and Hajinohur Area (Adzhinoursky-former Russian spelling) of Azerbaijan. Monograph, Ganja, p.104.

Bayramov, M. A. (2002). Model of ecological fertility of soil of the Jeyranchel Area of winter pasture: autoreferat of PhD's dissertation, Baku, p.24.

Hajiev, V. D. (1979). Registration and ways of improvement of winter pastures of Azerbaijan. In the book: 'Forage production' Scientific Research Institute of Forage named after V.D.Williams. M, P/house: 'Nauka', issue 20, pp. 66-72.

Grossgeym, A. A., \& Kolakovskiy, A. A. (1929). Geobotanical essay of winter pastures of the left-bank of Kura of the Kazakh Region. Baku, Issue: 'Narkozem', p.75

Museibov, M. A. (2001). Physical geography of Azerbaijan. P/house.: 'Elm', Baku, p. 200.

Prilipco, L. I. (1954). Plant cover of Azerbaijan. P/house.: ‘Elm', Baku, p. 120. 